\title{
Researching international schools: Challenges for comparative educational research
}

\author{
Anne Schippling
}

\begin{abstract}
:
For comparative educational research, the analysis of the field of international schools, from a global perspective, is a challenging area. In the last few decades, the number of international schools has increased worldwide, particularly in economically strong regions. Despite this the state of research remains generally modest, especially at the level of empirically consistent studies where a research deficit can be observed. Additionally, a shortage of analytical tools for researching international schools can be identified as this segment of education, determined by transnational phenomena, crosses over the national-states that are the traditional reference point of comparative educational research. In this contribution, firstly development tendencies such as the first appearance of the international school segment, influenced by international organisations such as Unesco, as well as their growth and diversification processes will be presented. Secondly, attention will be paid to the international state of research on international schools and research deficits will be shown. In the third part, there will be a reflection on the challenges of investigating international schools for comparative educational research.
\end{abstract}

Key words:

international schools; transnational spaces of education; comparative educational research 


\title{
Investigação sobre as escolas internacionais: desafios para a investigação educacional comparativa
}

\begin{abstract}
Resumo: Na área da investigação educacional comparativa, a análise das escolas internacionais a partir de uma perspetiva global é um desafio. Nas últimas décadas, o número de escolas internacionais tem vindo a aumentar a nível mundial, sobretudo nas regiões com uma economia forte. Apesar disso, o estado da investigação continua a ser modesto, de modo geral, especialmente no que diz respeito a estudos empiricamente consistentes, área onde se pode observar um défice de pesquisa. Para além disso, pode-se identificar uma escassez de instrumentos analíticos para pesquisar sobre as escolas internacionais, uma vez que esta área da educação, determinada por fenómenos transnacionais, transpõe as fronteiras dos estados-nação, que são o ponto de referência tradicional da investigação educacional comparativa. Nesta contribuição, serão apresentadas, em primeiro lugar, as tendências de desenvolvimento, tais como o surgimento da área das escolas internacionais, influenciada por organizações internacionais como a Unesco, assim como o seu crescimento e processos de diversificação. Em segundo lugar, centrar-nos-emos no estado, e respetivos défices, da investigação internacional sobre escolas internacionais. $\mathrm{Na}$ terceira parte, haverá uma reflexão sobre os desafios da investigação sobre escolas internacionais para a investigação educacional comparativa.
\end{abstract}

Palavras-chave: escolas internacionais; espaços de educação transnacionais; investigação educacional comparativa

\section{Recherche d'écoles internationales: défis pour la recherche en éducation comparée}

Résumé: En ce qui concerne la recherche en éducation comparée, l'analyse du domaine des écoles internationales d'une perspective globale est un sujet complexe. Au cours des dernières décennies, le nombre d'écoles internationales a augmenté dans le monde entier, surtout dans les régions plus fortes économiquement. Malgré cela, la réalité de la recherche reste généralement modeste, en particulier au niveau des études empiriquement constantes où un déficit de la recherche peut être constaté. De plus, un manque d'outils analytiques pour la recherche d'écoles internationales peut être identifié vu que ce segment du système éducatif, qui est déterminé par des phénomènes transnationaux, traverse les états nationaux qui sont le point de référence de la recherche en éducation comparée. Dans cette étude, en premier lieu, les tendances de développement tels que la première manifestation du segment de l'école international, influencée par des organisations internationales tels que l'Unesco, ainsi que leurs processus de développement et de diversification seront présentés. En second lieu, une attention particulière sera accordée à l'état de la recherche au niveau international des écoles internationales et des déficits de recherche seront présentés. En dernier lieu, une réflexion sera accordée aux défis de la recherche des écoles internationales pour la recherche en éducation comparée.

Mots-clés: écoles internationales; espaces d'apprentissage transnationaux; recherche en éducation comparée

\section{El estudio de los colegios internacionales: los retos para la investigación educativa comparada}

Resumen: Para la investigación educacional comparada, analizar el campo de las escuelas internacionales desde una perspectiva global es una tarea compleja. En las últimas décadas el número de colegios internacionales se ha incrementado en todo el mundo, especialmente en regiones cuya economía es fuerte. A pesar de ello, el estado actual de la investigación sigue siendo modesto en general, especialmente en lo que se refiere a estudios empíricos congruentes, donde se pueden observar déficits en la investigación. Además, resulta patente la escasez de herramientas de análisis para investigación de las escuelas internacionales, ya que este sector educativo, que es un fenómeno transnacional, atraviesa las fronteras de los Estados nación, que han sido tradicionalmente el punto de referencia para la investigación educativa comparada. En este artículo se presentarán en primer lugar las tendencias en el desarrollo, tales como la aparición del sector de las escuelas internacionales, influido por organizaciones internacionales como la Unesco, así como sus procesos de crecimiento y diversificación. En segundo lugar, se prestará atención al estado actual de la investigación internacional sobre la educación internacional y se mostrarán los déficits al respecto. En la tercera parte, se hará una reflexión sobre los retos que supone la investigación de los colegios internacionales para el estudio de la educación comparada.

Palabras clave: colegios internacionales; espacios educativos transnacionales; investigación educativa comparada. 


\section{The field of international schools: definition, origins and development tendencies}

The first challenge is to define what terms like "international education" or related ones like "international schools" mean". In her definition on schools that explicitly use the attribute "international" in their title, Hornberg (2010, p. 154) distinguished the following types:

- International schools in the form of schools abroad with elements of private schools, that are founded by a country in another country abroad and that offer the curriculum as well as the degree of the founding country.

- International schools in the form of private schools that offer the curriculum and the degree of the host state and that offer one or multiple foreign curricula or degrees.

- International schools in the form of private schools that offer international or foreign curricula or degrees (e.g. International Baccalaureate).

- State schools that offer their students international branches in addition to the national curricula and degrees.

The first school to use the attribute "international" in its title was the "International School of Geneva" or "École Internationale de Génève" founded in 1924 in Geneva. Mainly children of diplomats or employees from organisations linked to the United Nations attended the school, which still exists and still constitutes one of the biggest international schools worldwide with three locations in Geneva and about 4000 students of all nationalities. Like the "United Nations International Schools" (UNIS) founded in 1947 by the United Nations in New York, this school acted as a model for international schools founded later.

After the Second World War, the number of international schools constantly increased and many were founded as parent-run cooperatives responding to a local need for such schools. Two main explanatory approaches for this increase can be identified. On the one hand, there was a normative motive for their creation which aimed at promoting an intercultural dialogue and thus at contributing to a better international understanding and to peace in the world. The understanding of education formulated in Unesco's Universal Declaration of Human Rights in 1948 is an example of the normative motive for founding these schools:

Education shall be directed to the full development of the human personality and to the strengthening of respect for human rights and fundamental freedoms. It shall promote understanding, tolerance and friendship among all nations, racial or religious groups, and shall further the activities of the United Nations for the maintenance of peace (Unesco, 1948, Art. 26). 
There has been a significant influence of Unesco in the field of international education and the process of founding international schools. Unesco participated in the definition of the aims for international education and developed a detailed description of the characteristics of an "internationally minded" person (Kenworthy, 1947). In 1947, Unesco organised the first "Conference of Principals of International Schools" in Paris in which 15 schools participated (in more detail Hill, 2001).

Another explanatory approach is a pragmatic one and it's related to the increasing migration of highly qualified employees in global companies since the 1950s and the need for internationally compatible courses of education for the children of these employees. These two explanatory approaches do not exclude one another, but are rather complementary.

What is fundamental in order to understand the field of international schools is the fact that there are a number of international organisations partially recognised as non-profit organisations in the context of international schools, such as for example the International Schools Association (ISA), the International Baccalaureate ${ }^{\circledR}$ (IB) or the European Council of International Schools (ECIS). One object of the foundation of these organisations is the effort to standardise due to the variety of international schools, such as for example the introduction of an international curriculum or an internationally compatible higher education entrance qualification. Also in 1953, the Unesco founded the so-called Unesco Associated Schools, which can be understood as an international school model that explicitly intends to promote an international-understanding of education (Unesco, 2017).

There is a constantly growing number of international schools in a global perspective. For example, in the case of IB World Schools, in 2003 there were 1569 worldwide following the IB curriculum and by 2008 the number had risen to 2336 (Hornberg, 2010, p. 166); presently it is 4943 (IB, 2018). Besides the growing number of international schools a further differentiation of this type of school can be observed. One example is the foundation of international schools in countries like China, Dubai and Thailand that copy in the form of so-called "satellite schools" the model of English public schools such as for example Dulwich, Haileybury and Harrow in their respective countries. The school buildings are reconstructed according to the English original and school uniforms are imitated. The first of these schools was Dulwich College built in 1996 in Thailand. These schools - by means of offering a "western" education - try to contribute to the reproduction of the social status of the families attending these schools. Furthermore, commercially orientated groupings of international schools are arising more and more, for example, the Nord Anglia Group and Global Education Management Systems (GEMS) in economically highly developed areas like Hong Kong and Shanghai. 
In this context, one more line of development can be observed. The "traditional" international schools were established first and foremost for globally mobile families. These families represent a transnational elite characterised by the possession of "symbolic capital of education and language" which would "enable them to move freely, offering relatively easier access to border crossing and citizenship" (Bryceson \& Vuorela, 2002, p. 8). Ball and Nikita (2014, p. 82) call them a "global middle class" and a "burgeoning, mobile, post-national middle class who operate on a global scale".

A recently observable tendency is that international schools are not only in demand by a mobile global elite, but also by non-mobile middle-class families resident in the respective countries, like in the case of the "satellite schools". These parents want to give their children an advantage on the international education market by enabling them to attend such schools. On the one hand, these families expect an advantage by achieving international degrees like the IB diploma in order to have for example better chances of accessing top international universities (MacKenzie, Hayden \& Thompson, 2003). On the other hand, an English-medium education is said to improve employment opportunities in a global world market, which is also a reason why international schools are more and more in demand (MacKenzie, Hayden \& Thompson 2003; Hayden, 2011).

Alongside a more diversified student population in international schools and their expectations, the educational forms and concepts of these schools are also changing. Whilst the "traditional" international schools claimed more the idea of an "ideological promotion of international peace and understanding" in the course of increasing globalisation and marketization, a shift can be observed towards a more pragmatic education. This education aims primarily at preparing the children of these families for entry to a renowned university and for a high professional position, and is therefore contributing to the social and cultural reproduction of the mobile and non-mobile middle class (Hayden, 2011).

\section{State of research on international schools and the research desiderata}

Firstly, despite the increasing number of international schools worldwide and the corresponding heightened public awareness, a research deficit can be identified especially at the level of empirically consistent studies. This applies especially to international school models less prominent than the IB World Schools, such as, for example, the Unesco Associated Schools (Hornberg, 2010).

Empirical studies, mainly with a quantitative-oriented research design, can be found mostly in the Anglophone space, where the research on international schools is more developed. The work of the research group at the Centre for the Study of Education in an International Context (CEIC) at the University of Bath has taken centre stage since the 1990s. Its studies were based primarily on the results of questionnaires about the 
experiences and perceptions of school programmes on the part of pupils and teachers (Hayden \& Thompson, 1997; Hayden, Rancic \& Thompson, 2000). In relation to the attitudes of pupils towards "international education" it could be shown that their highest priority is the acquisition of an internationally compatible higher education entrance qualification, which indicates a strongly pragmatic orientation in relation to international education (Hayden \& Thompson, 1997, p. 474; Hayden, 2011, p. 219). In this context, the acquisition of English language played a central role. In more recent studies Hayden et al. (2000) determined that pupils and teachers associated "being international" with aspects such as "international mindedness", "second language competence", "flexibility of thinking" and "tolerance and respect for others". Furthermore, the perspective of the parents, especially in relation to questions of school choice, was explored in these studies (MacKenzie, Hayden \& Thompson, 2003).

Besides the empirical studies, there are more descriptive studies on the global landscape and development of international schools and their curricula and aims (Hayden \& Thompson, 2008, Bates, 2010).

In other European countries the state of research on international schools is less developed. There are some descriptive works about the situation and development of international schools, educational aims, organisational forms and curriculum programmes (Hornberg, 2010) and also empirical studies, which focus on the perspectives of pupils of international schools in relation to their expectations and attitudes towards their educational path and the roles of family and peers (Macedo, 2009; Keßler, Krüger, Schippling \& Otto, 2015) and the strategies of school choice of globally mobile parents (Forsey, Breidsenstein, Krüger \& Roch, 2015). Macedo (2009) investigated, in a qualitative empirical study, the construction of citizenship of young people at an international school in Portugal by analysing their expectations in relation to their personal and educational development and their ideas about their future professionality. Keßler, Krüger, Schippling \& Otto (2015) studied the school programme and the educational careers and orientations of young people at an international school in Germany in a longitudinal qualitative study and concluded that the pupils who study in an international context have a similar pragmatic orientation and identify themselves with the idea of world citizenship on the one hand, on the other, there can be found many differences in their educational orientations and perspectives (Keßler, Krüger, Schippling \& Otto, 2015). Forsey, Breidsenstein, Krüger \& Roch (2015) focused on the strategies of school choice of globally mobile parents in Berlin by analysing the online conversation threads about international schools in Berlin using an ethnographic design.

Furthermore, some empirical studies can be mentioned which refer to international schools in areas outside Europe. In a quantitative study about international and public schools in Qatar, for example, Kanan and Baker (2006) investigated the educational and professional visions for the future of pupils. In response to a research deficit on 
the children of non-mobile families who attend an international school within their own nation, Bailey (2015) confronted the research results of the analysis of the attitudes of children of the host-country nationals in an international school in Malaysia in relation to the significance of international schooling with the opinions of their expatriate teachers towards this subject.

Taking an overview of the international state of research on international schools it can be summed up that, especially in the Anglophone space, some studies can be found about the spread and development, educational concepts, forms of organisation and curricula of international schools. However, there is a worldwide deficit of empirical studies about international schools at the institutional level as well as on the level of the social actors in these schools. There is especially a need for longitudinal empirical studies, which would examine, for example, the educational paths of young people at international schools or the development of their peer contexts in both, formal and informal settings (Keßler, Krüger, Schippling \& Otto, 2015).

\section{Challenges of international school research for comparative educational research}

The research on international schools and their student body and related aspects is a rather neglected branch within comparative educational research. Areas scarcely looked at include the question of the mission and objective of international education and the question of contents of international curricula. In addition, the increasing influence of the network of non-state organisations around these schools, like the International Baccalaureate ${ }^{\circledR}(\mathrm{IB}, 2018)$ and the role of international organisations, such as Unesco, in the field of international education has received scant attention.

International schools are a research field that challenges comparative educational research from different perspectives. The nation-state paradigm has been the analytical reference basis in comparative educational research thus far, as formal national education systems are the main focus of this research (Adick, 2005). For researching international education, especially international schools, which can be understood as "transnational spaces of education" (Hayden, 2011; Keßler, Krüger, Schippling \& Otto, 2015), the traditional analytical tools of comparative educational research, determined by the nation-state paradigm, have to be reworked. Educational transnational phenomena have to be analysed in their special condition, and therefore an "adequate apparatus of concepts and analysis" (Adick, 2005, p. 246; also Resnik, 2012) is needed.

\section{Theoretical contexts}

Transnationalism, when considered a research programme trying to analyse processes of a current social change, has the main objective of overcoming the perspective 
of a methodological nationalism (Pries, 2010). The paradigm of a methodological nationalism is based on the assumption that national societies and nation-states are "natural reference units" for the investigation of social phenomena. In contrast, the research programme of transnationalism changes this perspective:

The transnationalism in its stricter sense used here mainly focuses on those social phenomena and social relationships which extend above several local units in different national societies, which are relatively stable and which contain comparatively dense interaction (Pries, 2010, p. 10).

The borders of a nation-state as reference unit tend to blur within this new perspective and the focus switches towards cross-border phenomena, which can extend over several national societies. In the context of his research about work migration between Mexico and the USA in the 1990s, Pries (1996) developed the concept of "transnational social spaces". The concept of space does not imply herein its traditional physical meaning of a location, but primarily designates relatively stable relationships between social actors that cross national borders.

Ulrich Beck (2000) in his reflections about "What is Globalization?" picks up the concept of transnational social space by Pries $(1996,2010)$ and states in this context: "[...] the approach centred in transnational social spaces maintains that something new is emerging: social contexts of life and action to which Here-and-There or Both-And applies" (Beck, 2000, p. 28).

The concept of a transnational social space refers to the transnational social practices of the actors, for example in the area of communication via the internet, which enables a social proximity of people who are not geographically closed. If these practices have a high level of stability and intensity, so that they are a part of everyday life, they could be named "transnational social spaces". ${ }^{1}$ An example is a transnational family, whose members are spread across the globe, but who have in their life practice durable and close relations and constitute, for that reason, a "transnational social space".

Because of the fact that the social actors in international schools, such as pupils and teachers, often belong to the globally mobile class, characterised by transnational experiences in their social practices and move in transnational social spaces, the theoretical concepts of the research on transnationality could be profitable for a comparative educational research dedicated to the question of international education (Teodoro, 2011).

In this context some first approaches exist which took up the concept of "transnational social space" and developed it for educational settings in the sense of "transnational social spaces of education". Adick (2005, p. 262), for example, characterised this concept with the following features: 
- transnational social spaces of education can arise "from the bottom", which means from the life practices of social actors, or "from the top", which means the promotion of transnational providers of education;

- they rely on already existing transnational convergences and promote more convergences;

- in transnational social spaces of education, cross-border processes of education take place;

- transnational social spaces of education are, in comparison to national or international spaces of education, non-governmental meaning not state-controlled, but organised "privately".

In relation to the research on international schools, Hayden (2011) introduced and developed the concept of "transnational spaces of education" with reference to Beck's (2000) theory and his concept of "transnational social spaces". According to her, international schools represent an answer to globalisation processes and "the aspirations of global knowledge workers for their children" (Hayden, 2011, p. 212).

\section{Research perspectives}

As shown before, in the area of the research on international schools there is a lack of empirical studies which investigate these schools and their environment at an institutional level, and also the perspectives of the pupils and their families and teachers of these schools.

Furthermore, some reflections will be developed on subjects and perspectives regarding the empirical field of international schools, where there is a special need for further research:

1. In the last few years, the composition of pupils who attend international schools has changed. Besides the population of children of globally mobile families, there appears to be a group of non-mobile host-country nationals with a higher social-economic background, who intend to secure for their children a good position in a globalised world, providing them an international education with an internationally recognised diploma. There is need for further research on this recently emerging social group in international schools, their educational paths and their family and peers.

2. The growth of the segment of the international schools is accompanied by a stronger diversification of these schools. New international school models are emerging as the private groupings of international schools like the Nord Anglia Education or the Phorms Education. The heterogeneity of the field of the international school models is a domain for further research. There are also more traditional international school models, such as the Unesco Associated Schools, characterised by a strong research deficit. Additionally fruitful as a research perspective are the different meanings of the term "international" associated with these different school forms. 
3. Besides the changing population of these schools and the emergence of new types of international schools, changes in the educational forms and concepts, which characterise these institutions, can be also observed. Greater emphasis is given to the pragmatic dimension of international education, for instance to gain better access to the most reputed international elite universities. A further research about the educational concepts of these schools as "transnational spaces of education" could be fruitful. Questions are also emerging about the paradigm of an English-medium and Anglo-centric form of education and what this means for cultural and linguistic diversity.

4. Another research perspective, regarding the rapid spread of international school models worldwide, is related to the possible impact of this development on the national education systems. What does it mean for national education when not only families with a transnational background attend these schools, but also the privileged domestic groups who can afford this education?

5. Related to this question is a need for research on new forms of social inequality caused by the spread of international schools. Is there a danger, as Hayden (2011, p. 221) pointed out, of "a growing educational gap between social groups and thus to growing inequality in societies" caused by the growth of the sector of international school models?

6. A research deficit can also be found regarding the environment of these schools. There is, for example, a need for research on the influences of the network of the non-governmental, partly privately organised bodies, such as the International Baccalaureate $^{\circledR}(\mathrm{IB})$, International Schools Association (ISA) or the International School Services (ISS) on the development of the international schools. In addition, the relation between international organisations like the OECD or the Unesco and international schools,is a research perspective for this field.

\section{Notes:}

1 This contribution is based on a postdoctoral research project entitled "A internacionalização da educação das elites em Portugal. Um estudo qualitativo sobre colégios internacionais na Grande Lisboa" (CIES-IUL, Martin-Luther-University Halle-Wittenberg) and funded by the Fundação para a Ciência e a Tecnologia (FCT) (Ref. SFRH/BPD/112406/2015), Lisbon. It is also related to the transnational cooperation project with the University of Göttingen "Learning to be a Global Citizen. Theoretical Perspectives and Methodological Approaches" (funded by FCT/DAAD),

2 Pries (2010) ideal-typically created two more levels of transnational phenomena characterised by a lower intensity and stability than the "transnational social spaces": the "transnational relations" and the "transnational networks". 


\section{References}

Adick, C. (2005). Transnationalisierung als Herausforderung für die International und Interkulturell Vergleichende Erziehungswissenschaft. Tertium Comparationis. Journal für International und Interkulturell Vergleichende Erziehungswissenschaft, 11(2), 243-269.

Bailey, L. (2015). The experiences of host country nationals in international schools. A case-study from Malaysia. Journal of research in international education, 14(2), 85-97.

Ball, S., \& Nikita, D. (2014). The global middle class and school choice: A cosmopolitan sociology. Zeitschrift für Erziehungswissenschaft, 17(3), 81-93.

Bates, R. (2010). Schooling internationally: Globalisation, internationalisation and the future for international schools. Abington: Routledge.

Beck, U. (2000). What is globalization? Cambridge: Polity Press.

Bryceson, D. F., \& Vuorela, U. (2002). Transnational families in the twenty-first century. In Bryceson, D. F. \& Vuorela, U. (Eds). The transnational family: New European frontiers and global networks (pp. 3-30). Oxford, New York: Berg.

Forsey, M., Breidenstein, G., Krüger, O., \& Roch, A. (2015). Ethnography at a distance: globally mobile parents choosing international schools. International Journal of qualitative studies in education, 28(9), 1112-1128.

Hayden, M. (2011). Transnational spaces of education: the growth of the international school sector. Globalisation, societies and education, 9(2), 211-224.

Hayden, M. \& Thompson, J. (1997). Student perspectives on international education: a European dimension. Oxford review of education, (23)4: 459-478.

Hayden, M., \& Thompson, J. (2008). International schools - Growth and influence. Paris: Unesco.

Hayden, M., Rancic, B., \& Thompson, J. J. (2000). Being international: student and teacher perceptions from international schools. Oxford review of education, 26(1), 107-123.

Hill, I. (2001). Early stirrings: the beginnings of the international education movement. International Schools Journal, 20(2), 11-22.

Hornberg, S. (2010). Schule im Prozess der Internationalisierung von Bildung. Münster: Waxmann.

Internationale Baccalaureate - IB. (2018). Facts and figures. Recovered from http://www.ibo.org/aboutthe-ib/facts-and-figures/

Kanan, H. M., \& Baker, A. (2006). Influence of international schools on the perception of local students in individual and collective identities, career aspirations and choice of university. Journal of research in international education, 5(3): 251-266.

Kenworthy, L.S. (1947). Social Studies teaching and international understanding. Unesco Seminar on Education for International Understanding (Sèvres). Paris: Unesco Archives.

Keßler, C., Krüger, H.-H., Schippling, A., \& Otto, A. (2015). Envisioning world citizens? Self-presentations of an international school in Germany and related orientations of its pupils. Journal of Research in International Education, 14(2), 114-126. 
Macedo, E. (2009). Cidadania em confronto: educação de jovens elites em tempo de globalização. Porto: CIIE/LIVPSIC.

Mackenzie, P., Hayden, M., \& Thompson, J. (2003). Parental priorities in the selection of international schools. Oxford review of education, 29(3), 299-314.

Pries, L. (1996). Transnationale soziale Räume. Theoretisch-empirische Skizze am Beispiel der Arbeitswanderungen Mexiko-USA. Zeitschrift für Soziologie, 25(6), 456-472.

Pries, L. (2010). Transnationalisierung: Theorie und Empirie grenzüberschreitender Vergesellschaftung. Wiesbaden: VS Verlag für Sozialwissenschaften.

Resnik, J. (2012). Sociology of international education: an emerging field of research. International Studies in Sociology of Education, 22(4), 291-310.

Teodoro, A. (2011). A educação em tempos de globalização neoliberal: os novos modos de regulação das políticas educacionais. Brasília: Liber Livro.

Unesco. (1948). The universal declaration of human rights. Recovered from http://www.UNESCO.org/ education/information/50y/nfsUNESCO/doc/hum-rights.htm

Unesco. (2017). Associated schools project network (ASPnet): About the network. Recovered from https://aspnet.UNESCO.org/en-us/Pages/About_the_network.aspx

Anne Schippling

Postdoctoral Researcher at the Centre for Research and Studies in Sociology - University Institute of Lisbon (CIES-IUL, ISCTE-IUL) and the Department of General Education at Martin-Luther-University Halle-Wittenberg, Germany Invited Lecturer at the FernUniversität in Hagen, Germany Research Fellow of the Fundação para a Ciência e a Tecnologia (FCT), Lisbon.

E-mail: anne.schippling@iscte-iul.pt ORCID: http://orcid.org/0000-0002-8794-5554

Correspondência

Anne Schippling CIES-IUL ISCTE-IUL

Av. das Forças Armadas 1649-026 Lisboa (Portugal)

Data de submissão: Outubro 2017

Data de avaliação: Fevereiro 2018

Data de publicação: Setembro 2018 